University of Pennsylvania Carey Law School

Penn Law: Legal Scholarship Repository

Faculty Scholarship at Penn Law

$9-22-2010$

\title{
Veiled Women in the American Courtroom: Is the Niqab a Barrier to Justice?
}

Anita L. Allen

University of Pennsylvania Carey Law School

Follow this and additional works at: https://scholarship.law.upenn.edu/faculty_scholarship

Part of the Civil Rights and Discrimination Commons, Constitutional Law Commons, Courts

Commons, Gender and Sexuality Commons, Law and Gender Commons, Law and Society Commons, Near Eastern Languages and Societies Commons, Other Religion Commons, Public Law and Legal Theory Commons, Race and Ethnicity Commons, Religion Law Commons, and the Women's Studies Commons

\section{Repository Citation}

Allen, Anita L., "Veiled Women in the American Courtroom: Is the Niqab a Barrier to Justice?" (2010). Faculty Scholarship at Penn Law. 320.

https://scholarship.law.upenn.edu/faculty_scholarship/320

This Article is brought to you for free and open access by Penn Law: Legal Scholarship Repository. It has been accepted for inclusion in Faculty Scholarship at Penn Law by an authorized administrator of Penn Law: Legal Scholarship Repository. For more information, please contact PennlawIR@law.upenn.edu. 


\title{
Veiled Women in the American Courtroom: Is the Niqab a Barrier to
}

\author{
Justice?
}

\author{
Anita L. Allen
}

The United States is home to millions of Muslims. ${ }^{1}$ American Muslims are "largely assimilated, happy with their lives, and moderate with respect to many of the issues that have divided Muslims and Westerners around the world."2 Experts disagree about whether the number of U.S. Muslims is closer to two million than to eight million, but no one doubts that Islam is now among the most practiced religions in the country. Like their Christians, Jewish, Buddhist and Hindu counterparts, many Muslims are devoutly religious. Michigan has more Muslims than any other U.S. state; in 2005 the Islamic Center of America, the largest of more than twelve hundred U.S. mosques, opened in Dearborn, Michigan. The ethnic and national origins of U.S. Muslims are diverse. Some of the millions of U.S. families who practice Islam are recent immigrants from Africa, the Middle East, Europe or Asia. Michigan has one of the highest concentrations of Muslims of Arab ancestry outside of the Arab world. However, about a third of U.S. Muslims are long-time U.S. residents and citizens. ${ }^{3}$ Of these, some were born into families who practice Islam, others converted to Islam as children or adults.

\footnotetext{
1 "Muslim Americans: Middle Class and Mostly Mainstream," in Pew Research Center [database online]. Available from http://pewresearch.org/assets/pdf/muslim-americans.pdf (last visited June 2, 2010). Pew describes its report as the "first ever nationwide survey to attempt to measure rigorously the demographics, attitudes and experiences of Muslim Americans.” (p. 3).

${ }^{2}$ Id. at 7.

${ }^{3}$ The Pew Research Center Report estimates the number of US. Muslims to be 2.35 million and states that "Roughly two-thirds (65\%) of adult Muslims in the U.S. were born elsewhere," and "Among native-born Muslims, roughly half are African American (20\% of U.S. Muslims overall), many of whom are converts to Islam.” Other estimates of the proportion of African Americans that comprise the Muslim population range from $40 \%$ to $85 \%$. African Americans are considered the largest group of nonimmigrant Muslims in the United States. Karan Fraser Wyche, “African American Muslim Women: an Invisible Group,” Sex Roles 51 (September 2004): 319-328.
} 
Among the indigenous U.S. Muslim population groups are African American adherents, and most Black Muslim women adopt Islamic dress. ${ }^{4}$

While most American Muslims dress in standard “western” secular clothing, some U.S. women who practice Islam dress modestly. A number wear hijab headscarves in everyday life, and keep their arms and legs covered. A few wear the niqab. The niqab is a garment worn outside the home or in the presence of unrelated men that cloaks a woman's head and neck, leaving only her eyes exposed. A very few US Muslim women don the burqa. The burqa is a full body mantle worn outside the home, cloaking the woman's entire body and face. Although American women who visit Muslim counties -including Secretary of State and former First Lady Hilary Clinton and Congresswoman and Nancy Pelosi, have donned modesty headscarves to show respect, not everyone in the U.S. accepts the sight of partly or fully “veiled” women. For many U.S. non-Muslims and many U.S. Muslims, too, face covering symbolizes female oppression and subservience, religious extremism and radical politics. Many women who wear headscarves report that they have experienced anti-Muslim discrimination, have been prohibited from wearing the veil in schools, and have even endured violent attacks. ${ }^{5}$ Professor of Islamic Studies Aminah McCloud argues that African American women who wear the hijab attract more hostility than Muslim immigrants because although many non-Muslim Americans may

\footnotetext{
${ }^{4}$ Converts to Islam in the U.S. are "among the most enthusiastic about wearing traditional women's attire." Donna Gehrke-White, The Face Behind the Veil: the Extraordinary Lives of Muslims Women in America (New York: Kensington Publication, 2006) 2-5. See also, Yvonne Yazbeck Hadda, Jane I. Smith \& Kathleen M. Moore, Muslim Women in America (New York: Oxford, 2006) 45 ("Most Muslim women who are black choose to adopt Islamic dress and Islamic names..."). As an aside, it has also been documented that African American women are known for their creativity in designing stylish garments that also attend to the modesty requirement. Id. at 13.

${ }^{5}$ Yazbeck, Muslim Women in America at 103-107.
} 
accept that immigrants dress differently, they may find it difficult to accept locals who wear headscarves. ${ }^{6}$

Governments around the world have banned or placed restrictions on wearing the burqa, niqab, and hijab. ${ }^{7}$ In 2009, Belgium banned the burqa and niqab from its public streets, incurring the price of immediate criticism. ${ }^{8}$ On the premise that Muslim modesty attire hinders communication or visual identification, in 2010, the Canadian province of Quebec introduced a bill requiring the removal of the niqab when seeking medical and other benefits or services from government. ${ }^{9}$ A year earlier, however, in a criminal case brought against Muslim men accused of raping a Muslim woman when she was a child, an Ontario court found that a judge could not deny the victim an opportunity to testify in court wearing her niqab, without first conducting a preliminary hearing to determine whether her professed religious beliefs and practices were sincere and deeply held. ${ }^{10}$ In 2004, the French government banned the hijab from public schools. ${ }^{11}$ More recently, the Senate approved by a great majority (246 to 1 ) a bill to ban full facial veiling from all

\footnotetext{
${ }^{6}$ Id. at 59-60 (taken from Aminah McCloud, African American Islam (New York: Routledge, 1995).

${ }^{7}$ I also address this question in Anita L. Allen, "Undressing Difference: The Hijab in the West," Berkeley Journal of Gender, Law and Justice 23 (2008): 208-224.

${ }^{8}$ Yassin Musharbash, "It Makes No Sense to Ban the Burqa," in Spiegel Online [database online]. Available from http://www.spiegel.de/international/europe/0,1518,687105,00.html (Last visited June 2, 2010); Reuters, "Muslim Woman in Italy Is Fined for Wearing Veil," New York Times, 5 May 2010, A12 (reporting that "a 26-year-old Tunisian woman has been fined for wearing a face veil while walking to a mosque in northern Italy.").

${ }^{9}$ Bill 94: An Act to establish guidelines governing accommodation requests within the Administration and certain institutions, available from http://www.assnat.qc.ca/en/travaux-parlementaires/projets-loi/projet-loi94-39-1.html (last visited June 2, 2010).

See also, Ian Austen, “Canada: Bill in Quebec Would Ban Veils in Dealings with Officials,” New York Times, 25 March 2010, A15.

${ }^{10}$ R. v. S. (N.) (2009), $\underline{2009} \underline{\text { CarswellOnt } 2268}, \underline{95} \underline{\text { O.R. }}$ (3d) 735 (Ont. S.C.J.).

${ }^{11}$ Recently, an Israeli court held that private Catholic school can ban Muslim teacher from wearing the Hijab. Dan Izenberg, “Court: Private School Can Bar Teacher from Wearing Hijab,” the Jerusalem Post, 5 September 2010. Available from: http://www.jpost.com/Israel/Article.aspx?id=187073
} 
public places. ${ }^{12}$ However, because the Council of State has warned that banning the veil from public places violates the French Constitution and the European Convention for the Protection of Human Rights and Fundamental Freedoms, the bill still risks being declared unconstitutional. ${ }^{13}$

Debates around the niqab also preoccupy courts and the public in Muslim countries. In 2010, the Cairo administrative Court upheld a ban on the niqab in university examination rooms. ${ }^{14}$ But in 2007 the Supreme Administrative Court of Egypt found on religious freedom grounds that the American University of Cairo could not ban the niqab from campus. It was permitted, though, to require brief unveiling for verification of identity. ${ }^{15}$ Turkey banned the hijab, niqab and burqa from its universities entirely, then took an about face on the niqab for a time, after the more comprehensive ban, which had been upheld by the European Court of Human Rights in 2004, ${ }^{16}$ led some girls to choose

\footnotetext{
${ }^{12}$ Elaine Ganley, "French Senate Passes Ban on Full Muslim Veils," The Washington Times, 14 September 2010. Available from: http://www.washingtontimes.com/news/2010/sep/14/french-senate-passes-ban-fullmuslim-veils/

${ }^{13}$ Lizzy Davies, “Nicolas Sarkozy’s Cabinet Approves Bill to Ban Full Islamic Veil,” the Guardian, 20 May 2010, 23. Recent veiling legislation in Spain almost followed the French example. In 2010, the Senate approved a ban against wearing the burqa in all public places. This bill was later rejected by a slim majority in the Parliament. However, the government announced it will introduce a different version of the bill later. Raphael Minder, “Spain’s Senate Votes to Ban Burqa,” New York Times, 23 June 2010.

Available from: http://www.nytimes.com/2010/06/24/world/europe/24iht-spain.html?ref=muslim_veiling (last visited July 18 2010). See also, Alan Clendenning \& Harold Heckle, Spain Rejects Burqa Ban - For Now in The Huffington Post [database online]. Available from: http://www.huffingtonpost.com/2010/07/20/spain-rejects-burqa-ban_n_653254.html (last visited July 20 2010).

${ }^{14}$ Jaclyn Belczyk, “Egypt Court Upholds Niqab Ban for University Examinations” in Jurist [database online]. Available from: http://jurist.law.pitt.edu/paperchase/2010/01/egypt-court-uphold-niqab-banfor.php (last visited June 3 2010).

${ }^{15} \mathrm{Id}$.

${ }^{16}$ Leyla Sahin v. Turkey, Eur. Ct. H. R. (Application No. 44774/98, Nov. 10, 2005). The European Court of Human Rights heard the case of a Turkish university student woman who had objected to a ban on the hijab in schools, a policy the Turkish Parliament reconsidered in 2008 because it was effectively excluding non-secular women from getting a university education at all. Today headscarves that cover the neck, the chador and the burqa are banned on campus; but traditional scarves tied under the chin are allowed. The European Court of Human Rights heard another case regarding the veil in Dahlab v. Switzerland (2001) V Eur Court HR 449. Here, a schoolteacher was banned from teaching in a primary school because she wore an "Islamic headscarf," but the case was dismissed as inadmissible. For a critique of these two court cases,
} 
piety over education. When the Turkish Parliament reinstated the hijab ban, some university students took to covering their hijab-hooded hair with wigs. ${ }^{17}$ Recently, Syria prohibited the wearing of niqab (but not the hijab) in its universities. ${ }^{18}$

In the U.S., there have been no sustained calls for local, state or federal government to ban the hijab, niqab or burqa from public places or schools. In fact, in contrast to the overwhelming majority of Europeans that support a ban against wearing the niqab, sixty five percent of Americans say they would oppose such a ban. ${ }^{19}$ I argue that a ban against wearing Islamic garments in the U.S. would clearly cross into a zone of constitutionally protected freedom of religion and personal liberty. The First Amendment of the U.S. Constitution protects freedom of religious belief and exercise: "Congress shall make no law respecting an establishment of religion, or prohibiting the free exercise thereof." Yet in the context of court appearances, court detention, drivers' license issuance and air travel, U.S. policymakers and courts have authorized laws and practices that interfere with Muslim women’s free exercise of their religion, namely, the wearing of modesty attire that conceals the hair or face from view.

Does government have a right to demand that women take off their modesty clothing? The Ninth Circuit Court of Appeals recently held that when a woman facing a

see Carolyn Evans, “The 'Islamic Scarf' in the European Court of Human Rights," Melbourne Journal of International Law 7 (2006): 52-74. (Evans criticizes the Court's reliance on stereotypes about Muslim women).

${ }^{17}$ Matt Porter, "Headscarves in Turkey Wave a Red Fleg” in Global Post [database online]. Available from: http://www.globalpost.com/dispatch/study-abroad/100209/headscarves-turkey (last visited June 3 2010).

18 The Associate Press, Syria: Islamic Scarf That Leaves Only Eyes Exposed Is Banned, New York Times, 19 July 2010, A9.

${ }^{19}$ Pew Research Center, "Widespread Support for Banning Full Islamic Veil in Western Europe, Most Americans Disapprove" in Pew Research Publication Center Publications [database online]. Available from: http://pewresearch.org/pubs/1658/widespread-support-for-banning-full-islamic-veil-western-europenot-in-america (last visited July 20 2010). 
parole violation charge for a misdemeanor offense is detained in a courthouse holding cell she can be required to remove her hijab for security reasons. ${ }^{20} \mathrm{~A}$ noteworthy, bellweather development because Michigan has the largest population of Muslims in the country, a recently adopted Michigan law allows judges to order Muslim women not charged with any crime to bare their faces in court or go home. Courtroom controls over attire are clearly warranted and necessary for the sake of security, order and decorum. Yet banning from the courtroom the niqab head-covering of a sincere, practicing Muslim woman of whose identity the court is certain, is intolerant and risks running afoul of the First Amendment principle of religious free exercise and other federal laws.

\section{The Michigan Niqab Case}

Michigan District Judge Paul Paruk dismissed Ginnah Muhammad's lawsuit against a car rental company when she refused to unveil. ${ }^{21}$ The rental company was seeking $\$ 3,000$ to cover repairs on an automobile leased to Muhammad, an African American Muslim. Muhammad said the car had been damaged by thieves. Although she wanted access to small claims court to litigate her claim, Muhammad did not wish to show her full face. She wanted to wear her niqab, as she did in daily life. Because she refused to uncover her full face in his courtroom, Judge Paruk dismissed Muhammad's case. The Michigan District Judges Association sided with Judge Paruk's decision to oust Muhammad. Civil liberties groups sided with Muhammad who believed, with many other devout Muslims, that the holy Quran, requires women to cover their bodies in the presence of men outside their families. While many practicing Muslims in the U.S. do not

\footnotetext{
${ }^{20}$ Khatib v. County of Orange, 603 F. 3d 713 (9th Cir. May 3, 2010).

${ }^{21}$ Muhammad v. Paruk, 553 F.Supp.2d 893 (E.D.Mich.2008).
} 
wear modesty attire, for those who do, the practice is central to their faith. When a judge demands that an otherwise orderly person with a valid legal claim remove religious attire or face dismissal of her suit, the judge unfairly and unreasonably burdens her right of religious free exercise.

The Supreme Court of Michigan appears to have sided with Judge Paruk. On June 17, 2009, by a vote of 5 to 2, the Supreme Court of Michigan adopted an amendment to Michigan Rule of Evidence $611 .^{22}$ The new rule, Michigan Rule of Evidence 611(b), provides that: "The court shall exercise reasonable control over the appearance of parties and witnesses so as to (1) ensure that the demeanor of such persons may be observed and assessed by the fact-finder, and (2) to ensure the accurate identification of such persons.” This amendment would presumably allow a judge to ask a party or witness entering the courtroom wearing a ski-mask, nylon stocking stretched over his head or a Ku Klux Klan hood to remove it for the duration of the proceeding. Yet Michigan Rule 611(b) was not adopted in response to ski masks, stockings or Klan hoods. It was adopted to provide positive legal authority for Michigan judges (like Judge Paruk), to order a woman wearing the niqab (like Ginnah Muhammad) to uncover her face or leave the courtroom. The niqab has been understandably reviled as a symbol of women's political oppression and subservience; but coercing a woman to remove an emblem of religious piety raises a specter of political oppression of another kind.

Other U.S. states have laws giving judges authority to control attire. Oregon has such a law, Uniform Trial Court Rule 3.010(1), authorizing exclusion of persons attired

\footnotetext{
${ }^{22}$ Amendment of Rule 611 of the Michigan Rules of Evidence, available from: http://courts.michigan.gov/supremecourt/Resources/Administrative/2007-13-08-25-09-Order.pdf (last visited June 3 2010).
} 
in ways that detract "from the dignity of the court." Yet an Oregon woman successfully appealed her theft conviction on the ground that the judge refused to allow a defense witnesses to testify when he declined to remove what the appeals court termed his "religious headgear" in the courtroom. ${ }^{23}$ The witness in question was the woman's husband, whom an appeals court held the presiding judge improperly excluded under a misapplication of Rule 3.010(1). This obscure Oregon case brings to mind Gandhi's historic encounter with a South African judge. Upon swearing the nation’s first "colored" bar member in a highly publicized and long-awaited ceremony, the judge asked Gandhi to remove his turban, presumably out of deference to the court. Gandhi reluctantly caved in, believing he had bigger battles to fight. But most Americans who wear religious attire in everyday life, are more like the Oregon man than like Gandhi: they have no bigger battles in view to salve their wounded dignity in the present. ${ }^{24}$

The niqab is an unusual garment in the U.S., but it is worn by U.S. women of varied ethnicities who practice Islam. While uncommon, Muslim modesty dress has led to publicized and litigated conflicts between Muslim women and public authorities. A Florida woman clashed with the Florida motor vehicle authority. ${ }^{25}$ Sultaana Freeman argued that state officials violated the Florida Constitution and the Florida Religious Freedom Restoration Act (FRFRA) when they revoked her driver's license because she refused to be photographed without her niqab. The FRFRA provides that "Government shall not substantially burden a person's exercise of religion even if the burden results

\footnotetext{
${ }^{23}$ State v. Allen, 113 Ore. App. 306, 308 (Or. Ct. App. 1992).

${ }^{24}$ Mohandas K. Gandhi, Gandhi An Autobiography: The Story of My Experiments With Truth, trans. Mahadev Desai (New York: Beacon Press, 1993).

${ }^{25}$ Freeman v. State, 2003 WL 21338619 (Fla.Cir.Ct. Jun 06, 2003) (NO. 2002-CA-2828). Affirmed by Freeman v. Department of Highway Safety and Motor Vehicles, 924 So.2d 48, 31 Fla. L. Weekly D537 (Fla.App. 5 Dist. Feb 13, 2006) (NO. 5D03-2296), rehearing denied (Mar 29, 2006).
} 
from a rule of general applicability," unless Government demonstrates that application of the burden to the person - (1) is in furtherance of a compelling governmental interest; and (2) is the least restrictive means of furthering that compelling governmental interest. ${ }^{26}$ Under FRFRA, Florida was required to show that it had a compelling interest in photographing drivers and that denying Freeman a license altogether was the "least restrictive” means of furthering its interest. Freeman's lawsuit, filed on her behalf by the ACLU of Florida, cited Colorado, Indiana and Nebraska cases in which courts had ruled that individuals with sincerely held religious beliefs are entitled to licenses without photographs. ${ }^{27}$ Those cases involved members of Christian sects who interpret the Bible’s "Second Commandment" against graven images to prohibit them from having their pictures taken. ACLU attorney Howard Marks, who argued Freeman’s case before Ninth Judicial Circuit Court suggested that the state was using her as a scapegoat in the "war

\footnotetext{
${ }^{26}$ A federal Religious Freedom Restoration Act of 1993, 42 U.S.C. § 2000bb, was found unconstitutional as applied to the states in City of Boerne v. Flores (1997). The passage of federal RFRA was a response by Congress to Supreme Court Free exercise decisions including Employment Division v. Smith, 494 U.S. 872 (1990). Prior to RFRA, the Court had held that minority religions are not relieved from the force of laws of general application, such as the nation's polygamy and controlled substance laws. The Employment Division case upheld the denial of unemployment benefits to two Native American men who lost their state jobs because they had consumed sacramental peyote as part of a Native American church ritual. Florida has adopted its own version RFRA that mirrors the federal statute, as follows:

Fla. Stat. Ann. §§761.01-761.05 (1998)

761.01 Short title.\#\&151; This act may be cited as the "Religious Freedom Restoration Act of 1998." 761.02 Definitions.\#\&151; - As used in this act:

(1) "Government" or "state" includes any branch, department, agency, instrumentality, or official or other person acting under color of law of the state, a county, special district, municipality, or any other subdivision of the state.

(2) "Demonstrates" means to meet the burden of going forward with the evidence and of persuasion.

(3) "Exercise of religion" means an act or refusal to act that is substantially motivated by a religious belief, whether or not the religious exercise is compulsory or central to a larger system of religious belief.

761.03 Free exercise of religion protected. $\# \& 151$;

(1) The government shall not substantially burden a person's exercise of religion, even if the burden results from a rule of general applicability, except that government may substantially burden a person's exercise of religion only if it demonstrates that application of the burden to the person:

(a) Is in furtherance of a compelling governmental interest; and

(b) Is the least restrictive means of furthering that compelling governmental interest.

(2) A person whose religious exercise has been burdened in violation of this section may assert that violation as a claim or defense in a judicial proceeding and obtain appropriate relief. ...

${ }^{27}$ Quaring v. Peterson, 728 F.2d 1121 (8 $8^{\text {th }}$ Cir.1984); Bureau of Motor Vehicles v. Pentecostal House of Prayer, Inc., 269 Ind. 361, 380 N.E.2d 1225 (Ind.1978); Dennis v. Charnes, 805 F.2d 339 (10 ${ }^{\text {th }}$ Cir.1984).
} 
against terror," when all she wanted to do was to be able to "drive her kids to the doctor or go grocery shopping. ${ }^{28}$ Following the litigation Florida amended the law to exempt the requirement of full face photo from FRFRA. ${ }^{29}$

A devout Pennsylvania woman clashed with officials at the State Correctional Institution at Graterford, Pennsylvania, who refused to allow her to visit her imprisoned son unless she agreed to remove her veil. ${ }^{30}$ The woman brought a lawsuit in federal court to enjoin the prison to allow visitation while veiled. The judge who heard her case determined that "requiring the plaintiff to remove her veil as a condition of her right to visit her son in prison constitutes substantially burdening her exercise of religion.”31 Pennsylvania, like Florida has a Religious Freedom Restoration Act statute. ${ }^{32}$ The judge's constitutional analysis in the Graterford prison case conformed to a model Congress and several states courts have established for thinking about what it means to respect the fundamental right to practice one's religion. This model indicates that government may not interfere with persons' free exercise of rights other than to further its compelling, that is, urgent and important, interests. When the government's compelling interests require burdens on religious free exercise, as they will from time to time, those burdens should be minimized. In considering means to further its compelling interests, the government must select practical means that are the least restrictive of religious freedom.

\footnotetext{
${ }^{28}$ John-Thor Dahlburg, “Court Battle Over Veil Pits Religion Against Security,” Los Angeles Times, 30 May 2003, available from: http://articles.latimes.com/2003/may/30/nation/na-veil30 (last visited 10 June 2010).

${ }^{29}$ Section 332.051 reads as follow: "Notwithstanding chapter 761 or s. 761.05 , the requirement for a fullface photograph or digital image of the identification card holder may not be waived."

${ }^{30}$ Bint-Ishmawiyl v. Vaughn, 1995 WL 461949 (E.D. Pa. 1995).

${ }^{31}$ Ibid.

3271 Pa. Stat. §2401-2407 (2002).
} 
Although the state has a "compelling interest in making sure that visitors to inmates are indeed the persons they profess to be" the burdens placed on the veiled woman must be the "least restrictive."33 Rather than excluding the veiled mother from visits, the court found that the prison should inform her of the visitation times and dates when female corrections officers are on duty, so that she can briefly unveil to establish her identity prior to contact with her son.

Without anticipatory safeguards in place directing officials to accommodate religious attire as required by law, a woman's unwillingness to remove the niqab can have dire consequences. The consequence can be denial of access to an incarcerated family member, illustrated by the Pennsylvania Graterford prison case; or denial of access to civil court, illustrated by the Michigan case. To toss out Muhammed's lawsuit because she wore the niqab, rather than to seek to accommodate her faith and lawsuit, was to ignore the demands of deference to religion.

It could be argued that since Michigan Rule 611(b) permits judicial discretion without requiring a judge to order the removal of Muslim modesty attire, it is lawful. Ideally a judge would not use his or her "reasonable control" authority to exclude religious attire unless first determining that exclusion was necessary to further a compelling state interest. However the amendment was adopted in the context of a dispute over the niqab, precisely to authorize an interference with religious free exercise. Given the rule's genesis and doubtful constitutionality, it is not surprising that the Michigan Supreme Court decision to adopt it was not unanimous. Two judges, Chief

\footnotetext{
${ }^{33}$ Ibid.
} 
Justice Marilyn Kelly and Justice Diane Hathaway dissented from the decision to amend the state's evidentiary rules.

\section{Reasonable Control of the Courtroom}

The Michigan Supreme Court sought to give judges the right to exercise "reasonable control.” ${ }^{34}$ It is hard to argue against a judicial power labeled "reasonable control." In the past American judges have sometimes failed to exercise "reasonable" control over states of dress and undress in their courtrooms. An extreme instance from the past, the New York judge who tried the infamous Rhinelander v. Rhinelander marriage dissolution case allowed the plaintiff wife to undress in front of a jury, putatively to buttress the claim that her wealthy white husband was not a victim of fraud. ${ }^{35}$ Intimate letters revealed that Mr. Kip Rhinelander had seen Mrs. Alice Rhinelander nude in sexual encounters before marriage and that he had to have known that she was "colored" when he married her-there was no fraudulent pretense of whiteness. ${ }^{36}$

More recently, judges have demanded that an African American attorney remove an African fabric kente cloth he said was required by his role as an officer of his church, ${ }^{37}$

\footnotetext{
${ }^{34}$ Amendment of Rule 611 of the Michigan Rules of Evidence, available from: http://courts.michigan.gov/supremecourt/Resources/Administrative/2007-13-08-25-09-Order.pdf (last visited June 3 2010).

${ }^{35}$ Rhinelander v. Rhinelander, 219 N.Y.S. 548 (N.Y. App. Div. 1927), aff'd 157 N.E. 838 (N.Y. 1927).

${ }^{36}$ Earl Lewis \& Heidi Ardizonne, Love on Trial: an American Scandal in Black and White (New York: W.W. Norton, 2001).

${ }^{37}$ Anita Womack, “Judge Tells Lawyer not to Wear Kente Cloth in Court” Times Daily, 23 May 1992, available from: http://news.google.com/newspapers?nid=1842\&dat=19920523\&id=iUweAAAAIBAJ\&sjid=MscEAAAAI BAJ\&pg=1385,3508784 (last visited June 3 2010).
} 
that a Jewish man remove his yarmulke skull cap, ${ }^{38}$ and that a Roman Catholic priest serving as an attorney in a criminal matter appear in court in non-clerical garb to insure a fair trial. ${ }^{39}$ One judge erroneously ordered a new trial because a witness who was a Roman Catholic priest testified in a personal injury case wearing his clerical collar. ${ }^{40}$ It is important to consider what kind of control over attire worn for religious purposes is truly reasonable, and specifically whether a society citing compelling state interests may justly restrict the wearing of face-coverings that are commended by religion.

In a 1991 Memorandum addressed to his state’s judges, New Jersey Chief Justice Robert N Wilentz directed judges he supervised not to restrict litigants or witnesses from dressing as they choose: "I do not believe we should try to influence how litigants or witnesses dress, absent something that approaches the obscene."41 (Muslim modesty attire is, by U.S. standards, virtually the opposite of obscene since it conceals breasts, sex organs and then some.) Furthermore, Justice Wilenz wrote, "I believe the fact finder, albeit the jury or the judge, should see the litigant or witness as the person wishes to appear and reach whatever conclusions flow from that 'fact.",42 Many jurists would find Wilenz's anything-short-of-obscenity standard, too permissive. But the U.S. and England share a legal heritage and a recent UK study calls for an open mind and case-by-case pragmatism in responding to religious attire.

\footnotetext{
38 Close-It Enters., Inc. v. Mayer Weinberger, 64 A.D.2d 686, 407 N.Y.S.2d 587 (2d Dept.1978).

${ }^{39}$ La Rocca v. Lane, 77 Misc.2d 123, 353 N.Y.S.2d 867 (N.Y.Sup. Mar 11, 1974), reversed on other grounds in La Rocca v. Lane, 47 A.D.2d 243, 366 N.Y.S.2d 456 (N.Y.A.D. 2 Dept. Apr 07, 1975).

${ }^{40}$ Ryslik v. Krass, 652 A.2d 767 (N.J. Super. Ct. App. Div. 1995).

${ }^{41}$ Ryslik, 652 A.2d at 770.

42 Ryslik, 652 A.2d at 770.
} 
Indeed the Equal Treatment Advisory Committee of the United Kingdom's Judicial Studies Board urged tolerance, sensitivity and pragmatism in its 2007 guidelines for managing religious attire worn by parties, witnesses, judges, jurors, lawyers and incidental courtroom staff: "There is room for diversity, and there should be willingness to accommodate different practices and approaches to religious and cultural observance." $^{43}$ The Board found that while sensitive, well-explained requests that a woman remove her niqab will sometimes be warranted by the facts and circumstances at hand, "it is often possible," the Board concluded, "to assess the evidence of a woman wearing a niqab.” Judges sometime take evidence over the telephone and some judges are sight-impaired, hence the judiciary may not consistently presume that "the veil represents a true obstacle to the judicial task." ${ }^{44}$ In sum, "In many cases, there will be no need for a woman to remove her niqab, provided that the judge is of the view that justice can be properly served. ${ }^{25}$ A recent case in England provides an example of the way sensitivity and consideration can resolve more complicated situations. In this case, a fully veiled woman was required to testify in court. Her counsel ensured in advance that the judge presiding over the case would be a woman. The counsel was screened from the Muslim woman's view by a large umbrella and the courtroom was guarded to ensure that other men did not enter during her testimony. In this manner, the woman was able to testify without the veil. ${ }^{46}$

\footnotetext{
${ }^{43}$ Equal Treatment Advisory Committee (ETAC) of the Judicial Studies Board (JSB), available from: http://www.jsboard.co.uk/downloads/etbb/2009_etbb_3_religon.pdf (last visited June 10 2010). Chapter 3.3 Religious Dress, 3-18/1.

${ }^{44} \mathrm{JSB}$, at 3-18/4

${ }^{45}$ JSB, 3-18/6.

${ }^{46}$ Caroline Bridge, “Case Reports: Practice: Evidence,” Family Law 37 (2007): 986.
} 
Tolerance, sensitivity and pragmatism are not inherently inconsistent with the popular US emphasis on judges having control over their courtrooms. Judges should have substantial control over their courtrooms, including the power to ban clothing or nudity that disrupts, demeans or trivializes the forum of justice. ${ }^{47}$ Judges can exercise control and yet be highly tolerant of person's style and religious preferences. A New Jersey judge was reversed when he held a female attorney in contempt of court for wearing slacks and a sweater in court. ${ }^{48}$ In the American northeast, slacks and a sweater are less formal professional attire than a black suit and tie. But, unlike Mickey Mouse ears, a Batman costume, a comically oversized sombrero, a pants and sweater outfit does not demean, trivialize or disrupt a courtroom.

Women of Muslim faith wearing the niqab are neither disruptive nor an affront. They have a right not to be observed, so long as they can be seen, heard and identified in other straightforward and appropriate available ways. ${ }^{49}$ As a constitutional matter, respect for religious freedom demands that there should be a very strong presumption against religious clothing bans and a strict requirement of accommodation in those instances in which the state asserts a truly compelling interest in undressing its people. U.S. courts should avoid the quick conclusion that the niqab is "a true obstacle to the judicial task.”

\footnotetext{
${ }^{47}$ State v. Allen, 113 Ore. App. 306, 308 (Or. Ct. App. 1992).

${ }^{48}$ In re De Carlo, 357 A.2d 273, 275 (N.J. Super. Ct. App. Div. 1976).

${ }^{49}$ Aaron J. Williams, "The Veiled Truth: Can the Credibility of Testimony Given by a Niqab-Wearing Witness be Judged Without the Assistance of Facial Expressions?,” University of Detroit Mercy Law Review 85 (2008): 273.
} 


\section{The Wider Constitutional Context}

The U.S. Supreme Court has not directly addressed restrictions on Muslim headscarves or facial veils. In the past, the Court has upheld laws aimed at compelling religious minorities to conform to a variety of majority practices. The Court's stance has been that "[w]e have never held that an individual's religious beliefs excuse him from compliance with an otherwise valid law prohibiting conduct that the state is free to regulate. ${ }^{50}$ In Kelly v. Johnson (1976), the Court identified law enforcement as a realm of public service in which the state may dictate uniform dress and hairstyles. ${ }^{51}$ In Goldman v. Weinberger, ${ }^{52}$ the Court upheld military policies limiting the right of an active duty Jewish rabbi and clinical psychologist to wear the yarmulke. However, the weight of the Courts' decisions point to recognition of a constitutional right of minority group members to wear distinctive religiously inspired garb as free exercise of belief, and to a strong presumption that they may do so in the courtroom and courthouse.

In the landmark U.S. Supreme Court case, Cohen v. California (1971), the Court threw out the disorderly conduct conviction of a California man who donned a jacket bearing the offensive words "F--k the Draft" in a court house corridor. ${ }^{53}$ The decision was not unanimous, but the majority stressed that the First Amendment is not obliterated simply because a man uses a single crude expletive to express his political position on military conscription. The Cohen decision rested on the requirements of freedom of expression protected by the First Amendment. The First Amendment also protects the

\footnotetext{
${ }^{50}$ Employment Division v. Smith, 494 U.S. 872, 878 (1990).

${ }^{51}$ Kelly v. Johnson, 425 U.S. 238 (1976).

${ }^{52}$ Goldman v. Weinberger, 475 U.S. 503 (1986).

${ }^{53}$ Cohen v. California, 403 U.S. 15 (1971).
} 
free exercise of religion. If the first Amendment protects tasteless jackets, it could be expected to protect tasteful modesty attire worn for religious purposes.

To an extent government may restrict attire and even hairstyles, consistent with the First Amendment. But the Court has never been understood to endorse blanket disregard for religious attire in the name of conformity. Thus in 2005 the U.S. Office of Civil Rights announced plans to intervene on behalf of a Muslim girl suspended from school for wearing a headscarf. The Benjamin Franklin Science Academy had suspended an 11-year-old Muslim, Nashala Tallah Hearn. The girl had refused to remove her hijab headscarf in class. A school dress code forbade wearing hats, bandanas and other head coverings in the classroom. Muslim civil rights groups and the U.S. Justice Department Office of Civil Rights criticized the suspension, which was soon lifted.

The 2009 Supreme Court's decision in Safford Unified School District v. Redding ${ }_{2}^{54}$ underscores the obligation of the state to recognize and respect female modesty. The case held that public school administrators violated a middle school girl's Fourth Amendment rights against warrantless search and seizure when they conducted a strip search to look for contraband ibuprofen. Prior to Redding, the Court had held that a "special needs" exception to the Fourth Amendment warrant requirement permits public schools to conduct non law-enforcement searches of children and youth in public schools to check for illegal drug use or possession of contraband. But with the Redding decision, the court recognized modesty as a limit of privacy on school's right to conduct bodily searches of youngsters. Redding was not the first time the Court acknowledged the importance of modesty. The first acknowledgment came in Union Pacific Railroad v.

${ }^{54}$ Safford Unified School District v. Redding, 557 U.S. _ _, 129 S. Ct. 2633 (2009). 
Botsford, ${ }^{55}$ Citing the importance of modesty and privacy, the case had held that a woman who filed a tort action alleging physical injuries need not submit to a medical examination at the request of the defendant. The notion that tort plaintiffs need not undergo a professional medical examination is now obsolete, but the notion that women have a "right to be let alone" that permits them to keep themselves covered in public lives on. The privacy sentiment advanced in the Botsford case has been enduring: "No right is held more sacred, or more carefully guarded, by the common law, than the right of every individual to the possession and control of his own person, free from restraint or interference of others, unless by clear and unquestionable authority of law."

Some U.S. judges are persuaded that hijab is protected free exercise. Accordingly, in 2007 a woman in Galveston, Texas was awarded \$17,250, after she alleged that a security guard refused to allow her to enter the courtroom unless she removed her headscarf "worn in observance of hijab.” ${ }^{57}$ Her case led to official measures to remind local "judges to be sensitive to the constitutional rights of people in the courtroom and specifically noting that people who wear their religious clothing or head wear are not required to remove [it] upon entering the courtroom.”58 The religious Free Exercise clause of the First Amendment must surely require toleration of the modesty garments of Muslim women. But hijab, which leaves a woman's face fully observable is not niqab, which leaves only a woman's eyes in view. Is the difference constitutionally relevant?

\footnotetext{
55 Union Pac. R.R. v. Botsford, 141 U.S. 250 (1891).

${ }^{56}$ Id. at 251.

${ }^{57}$ Boyd v. Texas, 301 Fed. App'x 363, 364-65 (5th Cir. 2008).

58 Ibid.
} 


\section{A “Compelling State Interest”}

Because religious free exercise is a fundamental constitutional liberty, and a liberty protected by religious freedom restoration statutes, the central question that must be addressed is whether the state has a compelling interest that warrants excluding niqab from the court room. Five main concerns—veracity, accountability, demeanor, identity

and fairness-have prompted courts to seek to exclude face-veiled women as parties and witnesses.

Government has a compelling interest in a judicial system governed by rules and procedures that enable those responsible for fact-finding-judges, lawyers, prosecutors and juries - to assess the veracity of witnesses and parties. The government also has a compelling interest in holding accusers accountable for the statements they make and serious allegations of wrong-doing the levy against others. As for veracity and accountability, niqab interferes with the obligation to confront those whom one has accused. Facing a niqab-draped woman satisfies the desire to look a person in the eye to compel accountability and thereby to assess veracity; but frustrates the ability to ascertain veracity on the evidence of overall facial expression and body language.

Demeanor is evidence of truthfulness and also of mental and emotional fitness to stand trial. Demeanor is evidence of character and of whether a person is making a serious effort to pay attention and show respect to others in court. Government has a compelling interest in a judicial system in which participants act with rationality, civility and seriousness. The sight of niqab-drapped women, invites inferences of femininity, modesty and religiosity; but blocks inferences of immaturity, indifference, anger, 
boredom or contempt. Behind her veil the Muslim party or witness might be sticking out her tongue, yawning, dozing, pursing or biting her lips, smirking, grinning or frowning.

While it may be easier to judge the veracity and demeanor of a person who is not wearing a veil than to judge the veracity and demeanor of a person who is, judges, lawyers and juries nevertheless have significant bases for judgment. They can rely upon assessments of the veiled woman's tone of voice, choice of words, and the consistency and plausibility of her statements. They can judge the woman based on the look and movement of her eyes, her carriage, her gait, her posture, the manner in which she uses her hands. The assessment of demeanor does not depend upon seeing the face or entire face of the speaker. In fact, “[a]ccording to the empirical evidence, ordinary people cannot make effective use of demeanor in deciding whether to believe a witness. On the contrary, there is some evidence that the observation of demeanor diminishes rather than enhances the accuracy of credibility judgments. ${ }^{, 59}$ In Morales v. Artuz, the Second Circuit Court of Appeals considered whether the defendant's right to confront a witness was violated when the key witness testified wearing sunglasses so “dark... that you can’t see through them." ${ }^{, 60}$ The court held that the jury was still able to observe the witness's delivery, nervousness, and body language. The court explained that it was more important that the jury was able to triangulate the observed demeanors with the substance of the testimony, the witness's opportunity to observe, the consistency of the testimony, and whether the witness had any hostile motive. It could be argued that the right to confront one's accusers goes to core public values and undercuts the right to veil. But that right to confront accusers cannot be interpreted as a right to force a person who is

\footnotetext{
${ }^{59}$ Olin Guy Wellborn III, “Demeanor,” Cornell Law Review 76 (1991): 1075.

${ }^{60}$ Morales v. Artuz, 281 F.3d 55 (2d Cir. 2002).
} 
completely willing to appear in a courtroom and questioned, to take of attire called for by her faith. The wearing of the niqab is a kind of personal religious conduct that courts must tolerate and accommodate.

As for identity, it is easy to verify the identity of a person whose full face is in plain view, but the female form behind the niqab could be almost anyone of similar weight, height and color. There are plenty of ways a judge or other court personnel can identify a woman short of asking her to appear for the duration of a trial unveiled. The guidelines of the Maryland state Attorney General for meeting the identification needs of Maryland courts call for asking a woman wearing a modesty veil to momentarily remove it in the presence of a female security officer. ${ }^{61}$

In 2005 a New Zealand judge ruled that two Muslim witnesses testifying for the prosecution in a criminal procedure could not testify while wearing a burqa. ${ }^{62}$ This case presented two difficulties. First, the burqa not only covers the face but the whole body; thus, the witnesses' body language would be difficult to assess beneath the burqa. Second, in a criminal case such as this one, testimony is more crucial than in a civil procedure. Namely, criminal cases depart from the relations between two parties and become a matter of public interest. The public has the right to a transparent and open criminal justice system and has an interest in the conviction of criminals. On the other hand, part of the defendant's right to fair trial should allow him to cross-examine

\footnotetext{
${ }^{61}$ Office of the Attorney General, State of Maryland, May 27, 2009, "Constitutional Law- Free Exercise Clause-Whether Deputy Sheriff May Require An Individual Entering A Courthouse To Remove A Religious Face Covering For Security Purposes." 94 Md. Op. Atty. Gen. 81, 2009 WL 1648560 (Md.A.G.). Available from: http://www.oag.state.md.us/Opinions/2009/94oag81.pdf (last visited 10 June 2010).

${ }^{62}$ Police v. Razamjoo [2005] DCR 408 (District Court, Auckland).
} 
witnesses whose faces are uncovered. The judge in this case ruled that the court and litigants should be able to see the faces of witnesses. Otherwise, the court stated, how could they know "that the person re-entering the witness box today is the same person who was there yesterday?” The court added that even with visual identification it is difficult to distinguish between people of similar build and facial characteristics. The court emphasized the significance of watching witnesses' faces while they are under cross-examination and the public's right to observe justice unfolding in the courts. Nevertheless, the court allowed for some accommodations for the witnesses. The court ruled that screens would be used to ensure that only the judge and counsel would see the witnesses' faces while they testified and that the court's staff would be comprised entirely of women. The court also ordered that steps be taken to ensure that the witnesses would not be seen unveiled in the entrance to the courtroom or when they departed. The court specifically mentioned that the witnesses were allowed to express their religious views by wearing a hat or scarf that covered their hair.

Finally, as for bias, the niqab will seem extreme and exotic to some judges, jurors, parties, witnesses, attorneys prosecutors and courthouse personnel. Ethnic prejudice and unfair bias may be amplified by the appearance of veiled women in a US court room.

The Constitution will not allow a blanket niqab removal policy based either on the need to judge demeanor or veracity, to identify, to compel accountability, or to identify and avert bias. If the state's interest in all of these is compelling, it may interfere with religious free exercise but must do so in the least restrictive manner. 